\title{
Should we abandon Kielland's forceps?
}

\author{
LINDA D CARDOZO, DONALD M F GIBB, JOHN W W STUDD, DEREK J COOPER
}

\begin{abstract}
To assess the risks associated with the use of Kielland's forceps 2708 consecutive deliveries were studied prospectively and the neonatal outcome related to the mode of delivery. Of the 1191 primigravidas, $279(23.4 \%)$ underwent instrumental delivery, of whom $65(5.5 \%)$ were delivered with Kielland's forceps. There was no difference in early neonatal outcome (as judged by Apgar scores, intubations, and admission to the special care baby unit) between these babies and those delivered normally or by non-rotational forceps, but a higher proportion of the $127(10.7 \%)$ delivered by emergency caesarean section were compromised.

Of the 1517 multigravid patients, only $57(3.8 \%)$ underwent instrumental delivery, $15(1.0 \%)$ by Kielland's forceps. Among these babies, also, the outcome was no worse than for those delivered normally, but the babies delivered by caesarean section showed a greatly increased incidence of low Apgar scores, intubations, and admission to the special care baby unit.

There were no stillbirths or neonatal deaths among babies delivered by Kielland's forceps, nor were there any cases of severe birth trauma or of obvious neonatal morbidity.
\end{abstract}

\footnotetext{
King's College Hospital, London SE5 9RS

LINDA D CARDOZO, MD, MRCOG, senior registrar in obstetrics and gynaecology

National University of Singapore, Kandang Kerbau Hospital for Women, Singapore

DONALD M F GIBB, MRCP, MRCOG, lecturer in obstetrics and gynaecology

Dulwich and King's College Hospitals, London

JOHN W W STUDD, MD, MRCOG, consultant obstetrician and gynaecologist

King's College Hospital Medical School, London

DEREK J COOPER, MSC, PHD, senior programmer/analyst

Correspondence and requests for reprints to: Dr Linda D Cardozo.
}

\section{Introduction}

The use of mid-cavity rotational forceps has decreased because of their association with poor neonatal outcome. Emergency lower segment caesarean section is now considered by some authorities to be preferable, ${ }^{1}$ especially when there is associated fetal hypoxia. Maternal mortality associated with emergency caesarean section, however, is still nearly 10 times that for vaginal delivery, with a much higher incidence of maternal morbidity, both physical and mental, after caesarean section. Hence it would be unreasonable to discard Kielland's forceps unless the baby can be clearly shown to gain by the surgical alternative.

The major studies reporting the dangers of Kielland's forceps compared neonatal outcome with "matched controls" undergoing either vaginal delivery ${ }^{2}$ or non-rotational forceps delivery. ${ }^{3}$ These are not valid comparisons, since they are not alternative methods of delivery for the fetus that requires mid-cavity rotation before delivery.

\section{Patients and methods}

This study was undertaken in the district maternity unit at Dulwich Hospital, which for the past eight years has used a conservative policy regarding induction of labour ${ }^{4}$ and a strict protocol for augmentation of labour using partograms and the labour stencil. ${ }^{6}$ All patients have continuous fetal heart rate monitoring during labour, and epidural analgesia is available on request.

Pushing with contractions during the second stage of labour is encouraged only when the patient expresses a desire to bear down and there is no set time limit for the duration of the second stage. Delivery is expedited if there is fetal distress, maternal exhaustion, or no measurable progress after two hours in the second stage.

Normal vaginal deliveries are conducted by the midwives and all instrumental or operative deliveries are carried out by the resident obstetric registrar or senior registrar. Any instrumental delivery which might prove difficult is performed in the operating theatre as a "trial." The level of the fetal head is assessed in fifths palpable abdominally, and forceps are never applied when there is more than one fifth palpable above the pelvic brim. A neonatal paediatrician is present at all instrumental deliveries and caesarean sections and records the baby's Apgar score together with any comments regarding birth trauma; he also decides when admission to the special care baby unit is indicated.

The obstetric features and neonatal outcome for the 2708 consecutive patients delivered during 1980 and 1981 were coded by LDC 
and DMFG before discharge from hospital. The information was installed on computer and analysed by the computerised statistical package for social sciences.

\section{Results}

Tables I and II list the obstetric features of the primigravidas and multigravidas respectively. Those patients who were delivered by elective caesarean section or in breech presentation or who had twin pregnancies were excluded (a total of 21 primigravidas and 46 multigravidas). Tables III and IV show the early neonatal outcomes in the two groups according to mode of delivery. In both groups the

TABLE I-Obstetric features of primigravidas

\begin{tabular}{|c|c|c|c|c|c|}
\hline & \multicolumn{5}{|c|}{ Mode of delivery } \\
\hline & $\begin{array}{l}\text { pontaneous } \\
\text { vaginal }\end{array}$ & $\begin{array}{l}\text { Non- } \\
\text { rotational } \\
\text { forceps }\end{array}$ & Ventouse & $\begin{array}{l}\text { Kielland's } \\
\text { forceps }\end{array}$ & $\begin{array}{c}\text { Emergency } \\
\text { LSCS }\end{array}$ \\
\hline $\begin{array}{l}\text { No }\left(1191^{*}\right) \\
0 \% \text { of total } \\
\text { Mean height }(\mathrm{cm})\end{array}$ & $\begin{array}{r}764 \\
64 \\
162\end{array}$ & $\begin{array}{r}180 \\
15 \\
162\end{array}$ & $\begin{array}{r}34 \\
3 \\
159\end{array}$ & $\begin{array}{r}65 \\
6 \\
161\end{array}$ & $\begin{array}{r}127 \\
11 \\
159\end{array}$ \\
\hline \multirow{3}{*}{$\begin{array}{l}\text { Labour: } \\
\text { Spontaneous }\left(0_{0}\right) \\
\text { Spontaneous }+ \\
\text { augmented }(0,0) \\
\text { Induced }(\circ, 0)+ \\
\text { Epidural analgesia } \\
\text { Mean duration of first } \\
\text { stage (hours) }\end{array}$} & 68 & 51 & 41 & 40 & 26 \\
\hline & $\begin{array}{r}25 \\
7 \\
19\end{array}$ & $\begin{array}{l}36 \\
13 \\
52\end{array}$ & $\begin{array}{r}50 \\
9 \\
52\end{array}$ & $\begin{array}{r}51 \\
9 \\
69\end{array}$ & $\begin{array}{l}55 \\
18 \\
64\end{array}$ \\
\hline & $\begin{array}{l}\text { st } \\
\text { cond } 5 \cdot 7\end{array}$ & $7 \cdot 6$ & $8 \cdot 1$ & $9 \cdot 0$ & $10 \cdot 1$ \\
\hline \multicolumn{2}{|c|}{$\begin{array}{l}\text { Mean duration of second } \\
\text { stage (min) }\end{array}$} & 64 & 63 & 78 & 73 \\
\hline
\end{tabular}

LSCS $=$ Lower segment caesarean section

*Includes 21 primigravidas who were excluded because of elective caesarean sections, breech presentation, or twins.

Induced with prostaglandin pessaries, artificial rupture of membranes, or oxytocin or combination of all three.

TABLE II-Obstetric features of multigravidas

\begin{tabular}{|c|c|c|c|c|c|}
\hline & \multicolumn{5}{|c|}{ Mode of delivery } \\
\hline & $\begin{array}{l}\text { Ppontaneous } \\
\text { vaginal }\end{array}$ & $\begin{array}{l}\text { Non- } \\
\text { rotational } \\
\text { forceps }\end{array}$ & Ventouse & $\begin{array}{l}\text { Kielland's } \\
\text { forceps }\end{array}$ & $\begin{array}{c}\text { Emergency } \\
\text { LSCS }\end{array}$ \\
\hline $\begin{array}{l}\text { No }(1517)^{*} \\
\text { o of total } \\
\text { Mean height }(\mathrm{cm})\end{array}$ & $\begin{array}{r}1347 \\
89 \\
162\end{array}$ & $\begin{array}{r}35 \\
2 \\
160\end{array}$ & $\begin{array}{l}7 \\
0.5 \\
156\end{array}$ & $\begin{array}{r}15 \\
1 \\
157\end{array}$ & $\begin{array}{r}67 \\
4 \\
158\end{array}$ \\
\hline \multirow{4}{*}{$\begin{array}{l}\text { Labour: } \\
\text { Spontaneous }\left({ }_{0}\right) \\
\text { Spontaneoous }+ \\
\text { augmented }\left({ }_{0}{ }_{0}\right) \\
\left.\text { Induced ( }\left({ }_{0}\right){ }^{+}\right) \\
\text {Epidural analgesia } \\
\text { Mean duration of first } \\
\text { stage (hours) } \\
\text { Mean duration of secono } \\
\text { stage (min) }\end{array}$} & 80 & 43 & 57 & 60 & 53 \\
\hline & $\begin{array}{r}13 \\
7 \\
5\end{array}$ & $\begin{array}{l}26 \\
31 \\
49\end{array}$ & $\begin{array}{l}29 \\
13 \\
67\end{array}$ & $\begin{array}{r}33 \\
7 \\
53\end{array}$ & $\begin{array}{l}11 \\
36 \\
24\end{array}$ \\
\hline & st $3 \cdot 3$ & $6 \cdot 2$ & $6 \cdot 5$ & $6 \cdot 8$ & $5 \cdot 1$ \\
\hline & cond 18 & 44 & 53 & 81 & 106 \\
\hline
\end{tabular}

LSCS = Lower segment caesarean section.
*Includes 46 multigravidas who were excluded because of elective caesarean sections, * Includes 46 multigravidas wh

+Induced with prostaglandin pessaries, artificial rupture of membranes, or oxytocin or combination of all three.

TABLE III-Early neonatal outcome for primigravidas

\begin{tabular}{lccccc}
\hline & \multicolumn{5}{c}{ Mode of delivery } \\
\cline { 2 - 6 } & $\begin{array}{c}\text { Spontaneous } \\
\text { vaginal }\end{array}$ & $\begin{array}{c}\text { Non- } \\
\text { rotational } \\
\text { forceps }\end{array}$ & Ventouse & $\begin{array}{c}\text { Kielland's } \\
\text { forceps }\end{array}$ & $\begin{array}{c}\text { Emergency } \\
\text { LSCS }\end{array}$ \\
\hline $\begin{array}{c}\text { Apgar score at 1 min } \\
\text { (mean) }\end{array}$ & $8 \cdot 1$ & $8 \cdot 2$ & $7 \cdot 4$ & $8 \cdot 0$ & $6 \cdot 6$ \\
$\quad$ o with score $\leqslant 5$ & $7 \cdot 3$ & $3 \cdot 3$ & $14 \cdot 7$ & $9 \cdot 2$ & $35 \cdot 0$ \\
$\begin{array}{c}\text { Apgar score at 5 min } \\
\text { (mean) }\end{array}$ & $9 \cdot 5$ & $9 \cdot 7$ & $9 \cdot 4$ & $9 \cdot 6$ & $8 \cdot 9$ \\
o with score $\leqslant 5$ & $3 \cdot 5$ & $1 \cdot 1$ & 0 & 0 & $8 \cdot 4$ \\
$\begin{array}{c}\text { Intubated (") } \\
\text { Stillbirths }\end{array}$ & $3 \cdot 4$ & $2 \cdot 8$ & $8 \cdot 8$ & $3 \cdot 1$ & $21 \cdot 3$ \\
Neonatal deaths & 9 & 1 & & & 1 \\
$\begin{array}{c}\text { Admitted to special } \\
\text { care baby unit ("0) }\end{array}$ & $2 \cdot 5$ & $3 \cdot 3$ & $5 \cdot 9$ & $1 \cdot 5$ & $12 \cdot 6$ \\
$\begin{array}{c}\text { Mean birth weight } \\
\text { (g) }\end{array}$ & 3200 & 3300 & 3250 & 3450 & 3400 \\
\hline
\end{tabular}

LSCS $=$ Lower segment caesarean section
TABLE IV-Early neonatal outcome for multigravidas

\begin{tabular}{|c|c|c|c|c|c|}
\hline & \multicolumn{5}{|c|}{ Mode of delivery } \\
\hline & $\begin{array}{c}\text { Spontaneous } \\
\text { vaginal }\end{array}$ & $\begin{array}{l}\text { Non- } \\
\text { rotational } \\
\text { forceps }\end{array}$ & Ventouse & $\begin{array}{c}\text { Kielland's } \\
\text { forceps }\end{array}$ & $\begin{array}{c}\text { Emergency } \\
\text { LSCS }\end{array}$ \\
\hline $\begin{array}{l}\text { Apgar score at } 1 \mathrm{~min} \\
\text { (mean) } \\
\text { of with score } \leqslant 5 \\
\text { Apgar score at } 5 \mathrm{~min}\end{array}$ & $\begin{array}{l}8 \cdot 4 \\
4 \cdot 9\end{array}$ & $\begin{array}{l}7 \cdot 9 \\
8 \cdot 6\end{array}$ & $\begin{array}{r}7 \cdot 4 \\
14 \cdot 3\end{array}$ & $\begin{array}{l}8 \cdot 1 \\
6 \cdot 7\end{array}$ & $\begin{array}{r}6 \cdot 0 \\
43 \cdot 2\end{array}$ \\
\hline $\begin{array}{l}\text { Apgar score at } 5 \mathrm{~min} \\
\text { (mean) } \\
\text { o with score } \leqslant 5 \\
\text { Intubated }\left({ }_{0}^{\circ}\right) \\
\text { Stillbirths } \\
\text { Neonatal deaths } \\
\text { Admitted to special }\end{array}$ & $\begin{array}{c}9.7 \\
1.9 \\
1.6 \\
10 \\
2\end{array}$ & $\begin{array}{l}9 \cdot 2 \\
5 \cdot 7 \\
5 \cdot 7 \\
1\end{array}$ & $\begin{array}{l}9 \cdot 4 \\
0 \\
0\end{array}$ & $\begin{array}{l}9 \cdot 3 \\
6 \cdot 7 \\
6 \cdot 7\end{array}$ & $\begin{array}{c}8 \cdot 1 \\
13 \cdot 4 \\
23 \cdot 9 \\
3 \\
1\end{array}$ \\
\hline $\begin{array}{l}\text { care baby unit }\left({ }^{\circ}\right) \\
\text { Mean birth weight } \\
\text { (g) }\end{array}$ & $\begin{array}{l}1.6 \\
3350\end{array}$ & $\begin{array}{r}0 \\
3600\end{array}$ & $\begin{array}{r}0 \\
3310\end{array}$ & $\begin{array}{r}6 \cdot 7 \\
3570\end{array}$ & $\begin{array}{r}8 \cdot 2 \\
3280\end{array}$ \\
\hline
\end{tabular}

LSCS $=$ Lower segment caesarean section

TABLE V-Neonatal outcome for primigravidas delivered for fetal distress

\begin{tabular}{|c|c|c|c|c|}
\hline & \multicolumn{4}{|c|}{ Mode of delivery } \\
\hline & $\begin{array}{l}\text { Non- } \\
\text { rotational } \\
\text { forceps }\end{array}$ & Ventouse & $\begin{array}{l}\text { Kielland's } \\
\text { forceps }\end{array}$ & $\underset{\text { LSCS }}{\text { Emergency }}$ \\
\hline $\begin{array}{l}\text { No }\left({ }^{\circ} \text { of total) }\right. \\
\text { Apgar score at } 1 \text { min (mean) } \\
\text { o with score } \leqslant 5 \\
\text { Apgar score at } 5 \text { min (mean) } \\
o \text { with score } \leqslant 5 \\
\text { Intubated }(\%) \\
\text { Admitted to special care baby }\end{array}$ & $\begin{array}{l}41(23) \\
7 \cdot 5 \\
9 \cdot 8 \\
9 \cdot 3 \\
4 \cdot 9 \\
7 \cdot 3\end{array}$ & $\begin{array}{l}6(18) \\
6 \cdot 8 \\
20 \cdot 0 \\
8 \cdot 6 \\
0 \\
16 \cdot 7\end{array}$ & $\begin{array}{c}10(15) \\
7 \cdot 7 \\
10 \cdot 0 \\
9 \cdot 6 \\
0 \\
10 \cdot 0\end{array}$ & $\begin{array}{l}21(19) \\
5 \cdot 9 \\
40 \cdot 0 \\
7 \cdot 5 \\
25 \cdot 0 \\
25 \cdot 0\end{array}$ \\
\hline $\begin{array}{l}\text { unit }\left(\begin{array}{l}0 \\
0\end{array}\right) \\
\text { Stillbirths + neonatal deaths }\end{array}$ & $5 \cdot 1$ & $16 \cdot 7$ & $10 \cdot 0$ & $\begin{array}{c}25 \cdot 0 \\
1\end{array}$ \\
\hline
\end{tabular}

LSCS $=$ Lower segment caesarean section

TABLE VI-Neonatal outcome for primigravidas delivered for failure to progress

\begin{tabular}{|c|c|c|c|c|}
\hline & \multicolumn{4}{|c|}{ Mode of delivery } \\
\hline & $\begin{array}{l}\text { Non- } \\
\text { rotational } \\
\text { forceps }\end{array}$ & Ventouse & $\begin{array}{l}\text { Kielland's } \\
\text { forceps }\end{array}$ & $\underset{\text { LSCS }}{\text { Emergency }}$ \\
\hline $\begin{array}{l}\text { No }\left({ }^{\circ}{ }_{0} \text { of total) }\right. \\
\text { Apgar score at } 1 \text { min (mean) } \\
\text { "o with score } \leqslant 5 \\
\text { Apgar score at } 5 \text { min (mean) } \\
\text { o with score } \leqslant 5 \\
\text { Intubated }(0) \\
\text { Admitted to special care baby }\end{array}$ & $\begin{array}{l}100(56) \\
8 \cdot 4 \\
1 \cdot 0 \\
9 \cdot 8 \\
0 \\
2 \cdot 0\end{array}$ & $\begin{array}{l}17(50) \\
7 \cdot 5 \\
13 \cdot 3 \\
9 \cdot 7 \\
0 \\
6 \cdot 7\end{array}$ & $\begin{array}{l}49(75) \\
7 \cdot 9 \\
13 \cdot 0 \\
9 \cdot 5 \\
0 \\
4 \cdot 3\end{array}$ & $\begin{array}{l}60(55) \\
6 \cdot 7 \\
30 \cdot 0 \\
9 \cdot 1 \\
6 \cdot 7 \\
24 \cdot 9\end{array}$ \\
\hline $\begin{array}{l}\text { unit }(0,0) \\
\text { Stillbirths + neonatal deaths }\end{array}$ & $\begin{array}{l}2 \cdot 0 \\
1\end{array}$ & 0 & 0 & $13 \cdot 4$ \\
\hline
\end{tabular}

LSCS $=$ Lower segment caesarean section.

outcome for babies delivered by Kielland's forceps was no worse than for those delivered normally or by non-rotational forceps, and was better than in those delivered by emergency caesarean section.

In the primigravid patients 18 of the caesarean sections were performed immediately after a failed trial of forceps or ventouse. These patients were not shorter than average (mean height $162 \mathrm{~cm}$ ) but they had a higher proportion of induced labours $\left(17^{\circ}\right)$, a longer mean first stage (11 hours), and a lower incidence of epidural analgesia $\left(44^{\circ}{ }^{\circ}\right)$. The mean Apgar scores of their babies at one and five minutes were 5.9 and 8.7 respectively, which was no lower than the mean scores for the other babies delivered by emergency caesarean section. None of the babies was stillborn or died in the neonatal period and there was no evidence of severe birth trauma or neurological abnormality. The mean birth weight of babies whose trial of forceps failed was $3520 \mathrm{~g}$, being greater than that for other modes of delivery. Only two of the multigravid mothers had a failed trial of forceps. Neither of their babies showed any evidence of birth asphyxia or trauma.

Patients who underwent instrumental delivery were divided into two groups according to the indication for intervention. Table $\mathrm{V}$ shows the neonatal outcome for those primigravidas whose delivery was expedited for fetal distress. Fetal distress was diagnosed by the senior resident obstetrician using the following criteria: major abnormalities of the intrapartum cardiotocogram (late decelerations or

\section{$\underline{\underline{\underline{T}}}$


persistent loss of beat to beat variation) or meconium stained liquor and a fetal scalp pH less than $7 \cdot 25$ in the first stage or $7 \cdot 20$ in the second stage of labour. Table VI gives the results for the primigravidas who underwent operative delivery for failure to progress or deep transverse arrest. Failure to progress was indicated by no increase in cervical dilatation after six hours of augmentation with oxytocin in the first stage of labour or failure of head descent or rotation after two hours in the second stage. Patients who were delivered instrumentally for a combination of reasons or for whom no indication was stated in the case notes are excluded from tables $\mathrm{V}$ and VI. The numbers for multigravidas were too small to analyse when divided according to indication for intervention.

\section{Discussion}

During the past 20 years the caesarean section rate has doubled in Britain and trebled in the United States of America. The apparent justification is that during the same period perinatal mortality has fallen dramatically. O'Driscoll and Foley, however, have shown that the fall in perinatal mortality was independent of the increase in the caesarean section rate, ${ }^{7}$ which remained at less than $5 \%$ in their unit. This was also our finding, with a perinatal mortality of $0.9 \%$ and a caesarean section rate of $9 \%$.

Caesarean section is not always avoidable; nevertheless, many patients with deep transverse arrest, persistent occipitoposterior position, or simply delay in the second stage of labour due to poor maternal expulsive efforts who would previously have had a simple instrumental vaginal delivery are now undergoing caesarean section in the belief that this is best for the neonate. Our data fail to substantiate this and, in fact, show that overall more babies have lower Apgar scores after caesarean section than after Kielland's forceps delivery regardless of the indication for operative delivery. If it is not in the baby's interest to be delivered by caesarean section it is certainly of no benefit to the mother. Caesarean section still carries a maternal mortality roughly 10 times that of vaginal delivery and there is a much higher incidence of morbidity. After caesarean section a new mother finds it more difficult to look after her baby and she stays in hospital longer. She and her husband are deprived of the experience of "childbirth"-this time and possibly for ever. Why, then, has there been such a substantial move away from Kielland's forceps delivery?

Chiswick and James, in a retrospective uncontrolled study, found an increase in neonatal morbidity in babies delivered by Kielland's forceps when there had been evidence of fetal distress in labour. ${ }^{2}$ But when there had been no signs of fetal hypoxia the outcome for babies born by Kielland's forceps was the same as for those delivered spontaneously. We cannot know whether the outcome for the hypoxic fetuses would have been better had they been delivered by caesarean section, but it is unrealistic to compare their outcome with that of infants delivered spontaneously. Chiswick reported an increased incidence of transient "irritability" or "apathy" among neonates delivered by Kielland's forceps, but these signs had disappeared by seven days and none of the children were handicapped at two years. ${ }^{8}$

Comparing the results of Kielland's forceps delivery with non-rotational forceps delivery, Paintin and Vincent found very little difference in neonatal outcome. ${ }^{3}$ Healy et al compared the results of Kielland's forceps delivery with manual rotation and forceps delivery. ${ }^{9}$ Although retrospective, the study was large and the comparison valid. They found no difference in maternal or fetal morbidity regardless of whether the indication for intervention was delay in the second stage or fetal distress. The same was true in our series, where infants delivered by non-rotational forceps did little better than those delivered by Kielland's forceps and the outcome of ventouse deliveries was, if anything, worse. We found hardly any difference in neonatal outcome between patients delivered for fetal distress and those delivered because of failure to progress.

The change of practice in North America has been dramatic, the caesarean section rate rising past $30 \%$ in response to the surge of lawsuits for malpractice, partly due to the anti-midcavity forceps philosophy of many perinatologists. In 1980 Friedman was still quoting a stillbirth rate of $4 \%$ due to midforceps delivery in abnormal labour and a stillbirth rate of $1 \%$ in normal labour. His data, however, had been collected at least 15 years earlier, ${ }^{10}$ when intrapartum fetal monitoring was not routinely used and placental insufficiency and intrauterine growth retardation were poorly understood. Now, with the advent of ultrasound, patients at high risk may be identified and monitored carefully and the baby delivered before it suffers irrevocable hypoxic damage. Friedman et al also reported significantly decreased IQs among their patients delivered by midforceps ${ }^{11}$ - but those data, too, were outdated; and Chiswick's more recent series ${ }^{8}$ shows no long term deficit which can be attributed to the use of mid-cavity forceps.

Undoubtedly Kielland's forceps are potentially dangerous, but we are unable to show any deleterious effects associated with their careful use by skilled obstetricians in our population. We do follow certain criteria for their use, however, which support and extend the safeguards proposed by Paintin, ${ }^{12}$ and we think that these play an important part in preventing any morbidity due to instrumentation:

(1) The fetal head should be no more than one fifth palpable abdominally irrespective of the vaginal station of the head.

(2) There should not be excessive moulding.

(3) Adequate analgesia is essential, preferably by a lumbar epidural block.

(4) The senior resident obstetrician should conduct the delivery.

(5) When there is any doubt about the mode of delivery forceps should be used as a trial in the operating theatre with everything ready for an emergency caesarean section.

(6) If the blades cannot be applied easily or the head rotated with light pressure the procedure should be abandoned and an emergency caesarean section performed.

(7) Only moderate traction throughout a maximum of three contractions should be used.

From our data it would be illogical to dispose of Kielland's forceps in favour of caesarean section, as this confers no benefit to the newborn infant and is detrimental to the mother.

\section{References}

1 Chez RA, Ekbladh L, Friedman EA, Hughey MJ. Mid-forceps delivery: is it an anachronism? Contemporary Obstetrics/Gynaecology 1980; $15: 82-100$.

2 Chiswick ML, James DK. Kielland's forceps: association with neonatal morbidity and mortality. $\mathrm{Br}$ Med F 1979; :7-9.

3 Paintin DB, Vincent F. Forceps delivery-obstetric outcome. In: Beard RW, Paintin DB, eds. Outcomes of obstetric intervention in Britain. Proceedings of a scientific meeting of the Royal College of Obstetricians and Gynaecologists. London: RCOG, 1980:17-32.

4 Williams RM, Thom MH, Studd JWW. A study of the benefits and acceptability of ambulation in spontaneous labour. Br f Obstet Gynaecol $1980 ; 87: 122-5$.

${ }^{5}$ Cardozo LD, Gibb DMF, Studd JWW, Vasant RV, Cooper DJ. Predictive value of cervimetric labour patterns in primigravidae. $\mathrm{Br} \mathcal{F} \mathrm{Med}$ Gynaecol 1982;89:33-8.

6 Studd JWW. Partograms and nomograms of cervical dilatation in the management of primigravid labour. $\mathrm{Br} M e d \mathcal{f} 1973$;iv:451-5.

7 O'Driscoll K, Foley M. Correlation of decrease in perinatal mortality and increase in caesarean section rates. Obstet Gynecol 1983;61:1-5.

${ }^{8}$ Chiswick ML. Forceps delivery-neonatal outcome. In: Beard RW, Paintin DB, eds. Outcomes of obstetric intervention in Britain. Proceedings of a scientific meeting of the Royal College of Obstetricians and Gynaecologists. London: RCOG, 1980:33-45.

${ }^{9}$ Healey DL, Quinn MA, Pepperall RJ. Rotational delivery of the fetus: Kielland's forceps and two other methods compared. $\mathrm{Br} \mathcal{F}$ Obster Gynaecol 1982;89:501-6.

${ }^{10}$ Friedman EA, Sachtleben MR. High risk labor. $\mathcal{F}$ Reprod Med 1971;7: 28-32.

11 Friedman EA, Sachtleben MR, Bresky PA. Dysfunctional labor XII. Long term effects on infant. Am $\mathcal{F}$ Obstet Gynecol 1977;127:779-83.

12 Paintin DB. Mid-cavity forceps delivery. Br $\mathcal{F}$ Obstet Gynaecol 1982;89 495-6.

(Accepted 25 April 1983) 